\title{
PRZEOBRAŻENIA FUNKCJONALNO-PRZESTRZENNE MIAST TRADYCYJNEGO REGIONU SPOŁECZNO-EKONOMICZNEGO - WYMIAR TEORETYCZNY
}

\author{
FUNCTIONAL AND SPATIAL TRANSFORMATIONS OF TOWNS \\ IN A TRADITIONAL SOCIO-ECONOMIC REGION - \\ A THEORETICAL APPROACH
}

\begin{abstract}
NR DOI: $10.25167 / \mathrm{sm} 2018.032 .02 \quad$ s. $21-33$
ABSTRAKT: Pierwszym celem badania jest określenie aktualnego stanu wiedzy na temat funkcjonalno-przestrzennych przekształceń złożonych systemów osadniczych, przede wszystkim w tradycyjnym regionie społeczno-gospodarczym. Drugim jest zaproponowanie kilku modeli (cyrkulacyjnego ujęcia przemian gospodarczych oraz urbanizacyjnych). Punktem wyjścia dla badań autora jest próba modelu pochodzenia i ewolucji bazy ekonomicznej jako kluczowego elementu zmiany w przestrzeni społeczno-gospodarczej. Zmiany gospodarcze i urbanizacja są komplementarne, odzwierciedlają zarówno dośrodkowe, jak i odśrodkowe siły warunkujące transformację całego systemu osadniczego.
\end{abstract}

SŁOWA KLUCZOWE: złożony system osadniczy, model cyrkulacyjny przekształceń gospodarki i urbanizacji, baza ekonomiczna, siły dośrodkowe i odśrodkowe, województwo śląskie

ABSTRACT: The first goal of the study is to outline the current state of knowledge on functional-spatial transformations of complex settlement systems, especially those existing in traditional socio-economic regions. The second task is to propose a few model approaches (circular models of economic transformations and urbanization). The author's starting point is an attempt to model the origin and evolution of the economic base as a crucial element of the remaining changes in the socio-economic space. A model of economic changes and urbanization are complementary to each other, reflecting both the centripetal and centrifugal forces conditioning transformation of the entire settlement system.

KEY WORDS: complex settlement system, circular model of economic changes and urbanization, economic base, centripetal and centrifugal forces, Silesian Voivodeship

\section{Wprowadzenie}

Trzy struktury determinują przeobrażenia miast i regionów - struktura funkcjonalna, struktura przestrzenna oraz struktura demograficzno-społeczna. Pierwsza z nich - funkcjonalna - wskazuje na dominujące działalności gospodarcze, zwłaszcza

\footnotetext{
* Uniwersytet Śląski w Katowicach, Katedra Geografii Ekonomicznej, e-mail: jerzy.runge@us.edu.pl
} 
w układzie: sektor egzo- i endogeniczny. Sektor egzogeniczny koncentruje podstawowe działalności gospodarcze, które determinują rolę miasta bądź regionu w szerszej skali przestrzennej, a zarazem decydują o zakresie udziału w rynku pracy. Drugi z sektorów - endogeniczny - to działalności gospodarcze zaspokajające podstawowe potrzeby ludności. Struktura przestrzenna odzwierciedla zróżnicowanie morfogenezy i morfologii form użytkowania w obrębie jednostki terytorialnej. Jest efektem lokalizacji, zmian oraz nakładania się na siebie różnego typu działalności człowieka. Z kolei trzecia ze struktur - demograficzno-społeczna - ilustruje zróżnicowanie procesów oraz struktur ludnościowych, poszukując prawidłowości przestrzennych w sytuowaniu się człowieka oraz charakterystyk demograficzno-społecznych w obrębie miasta bądź regionu (płeć, wiek, wykształcenie, aktywność zawodowa).

O ile dwie pierwsze struktury ilustrują „świat rzeczy”, tj. materialny wymiar przestrzeni, o tyle trzecia ze struktur to „świat człowieka”, który zarówno ma wymiar realny, jak i przejawia się w formie zjawisk, procesów pozamaterialnych. Realny wymiar świata człowieka to zjawiska ludnościowe dostrzegalne w przestrzeni (np. rozmieszczenie skupisk ludności, zmiany w liczbie ludności, składowe przyrostu rzeczywistego, zróżnicowania etniczno-językowe, religijne). Z kolei pozamaterialny wymiar świata człowieka dotyczy jego poglądów, formułowanych ocen, np. w zakresie relacji społecznych, odczuć, świadomości i tożsamości terytorialnej.

Wskazane trzy podstawowe struktury miasta bądź regionu podlegały różnym próbom konceptualizacji. I tak w zakresie struktury funkcjonalnej najczęściej w dotychczasowej literaturze odwoływano się do modelu bazy ekonomicznej czy też do modelu trzech sektorów gospodarki; w zakresie struktury przestrzennej - do typologii użytkowania przestrzeni miejskiej, teorii regionu, koncepcji ładu przestrzennego czy też typów morfologicznych miast; zaś w przypadku struktury demograficzno-społecznej były to na ogół modele struktury społecznej miasta, modele rozwoju społecznego, teoria migracji czy też koncepcja urbanizacji.

Celami niniejszego opracowania są: po pierwsze, próba przybliżenia dotychczasowego stanu wiedzy na temat kształtowania się struktury funkcjonalno-przestrzennej złożonych układów osadniczych, w tym zwłaszcza tradycyjnych regionów społeczno-gospodarczych, zaś po drugie - propozycja cyrkulacyjnego ujęcia przemian gospodarczych oraz urbanizacyjnych. W porównaniu z aglomeracjami policentryczne układy osadnicze typu konurbacyjnego wykazują jak dotąd mniejszy zasób badań, w tym szczególnie modelowego ujęcia ich struktury oraz przemian (m.in. Friedmann 1967; Blotenvogel 1983; Rykiel 1985; 1991; Kaszowska, Pukowska-Mitka, Runge 1992; Krzysztofik 2014; Runge 2015; 2016), co niewątpliwie wynika ze złożoności konceptualizacji wieloelementowych, względnie zrównoważonych struktur osadniczych.

\section{Struktura funkcjonalno-przestrzenna a baza ekonomiczna}

Wiele z koncepcji charakteryzujących wymienione wyżej struktury miasta pojawiło się w XX w., a niektóre nawet jeszcze wcześniej, bo pod koniec XIX stulecia, co rodzi 
podstawowe pytanie o współczesną adekwatność ich założeń, zwłaszcza w świetle wzrastającej złożoności procesów społeczno-gospodarczych, tj.: modernizacji, globalizacji, transformacji, suburbanizacji. Wzmiankowane koncepcje posiadają wiele założeń idealizujących i upraszczających, w tym odwołania przede wszystkim do miast i regionów bez uwzględnienia rodzaju ich otoczenia. Między innymi N. Kunzmann (2010) zwraca uwagę na fakt, iż otoczenie determinuje możliwości przemian - usytuowanie miasta w centrum złożonego układu działa pozytywnie, bo wzmaga możliwości rozwoju; usytuowanie w strefie zewnętrznej złożonego układu pozwala wykorzystać tylko część możliwości rozwojowych, zaś położenie poza złożonym układem osadniczym stawia miasto w pozycji peryferii. To samo dotyczy regionów - bliskość innych regionów, zwłaszcza będących co najmniej na tym samym poziomie rozwoju społeczno-ekonomicznego, może być elementem motywującym do rozwoju, współpracy międzyregionalnej czy też twórczej konkurencyjności. Gorzej, jeśli region cechuje się narastaniem problemów w sytuacji braku bądź niedostatecznego sąsiedztwa regionów mogących stanowić wsparcie w przemianach.

\section{Struktura funkcjonalna}

W piśmiennictwie geograficzno-ekonomicznym wskazuje się na fakt, iż zazwyczaj strukturą inicjalną w przemianach jest struktura funkcjonalna. W zależności od wielkości, zróżnicowania oraz kierunku przemian bazy ekonomicznej miasta bądź regionu zmieniają się składowe struktury przestrzennej i demograficzno-społecznej. Wynika to z tezy o priorytecie gospodarki w kształtowaniu procesów rozwojowych. Wystarczy spojrzeć na miasta formowane w kolejnych etapach zmian cywilizacyjnych. Podobnie jest w przypadku regionów. Jak stwierdza Z. Chojnicki (1996), pierwszym etapem $\mathrm{w}$ formowaniu regionów jest krystalizacja materialna, tj. pojawienie się podstaw gospodarczych. Z kolei utrata znaczenia miejsca na mapie gospodarczej owocuje regresem miejscowości bądź regionu.

O ile do rewolucji przemysłowej kształt urbanistyczny miasta, pełnione funkcje oraz mieszkańcy stanowili wyraźną jedność terytorialno-funkcjonalną, o tyle późniejsze w czasie miasta przemysłowe i postindustrialne już niekoniecznie. Rozwój transportu przyczynił się do odejścia od założeń jedności terytorialno-funkcjonalnej, inicjując poszerzanie działalności gospodarczych zarówno strukturalnie, jak i przestrzennie. Z jednej strony według W. Zelinsky’ego (1971) przemieszczenia przybierają kierunek odśrodkowy (z centrów na peryferie), lecz z drugiej - przede wszystkim intensyfikują się przemieszczenia pomiędzy złożonymi układami osadniczymi. Miasto jako zorganizowany, do tej pory spójny układ gospodarczo-społeczny przekształca się w wieloelementową przestrzeń z najczęściej rozmytymi granicami jednostek strukturalnych przestrzeni miejskiej bądź regionalnej.

Jednocześnie wraz z rozwojem badań miejskich i regionalnych konieczne jest dostrzeganie zjawiska różnicowania kierunków i natężenia zmian analizowanych struktur. O ile do XX w. podkreślano współzależność w zakresie rozwoju gospodarczego, 
ludnościowego i przestrzennego miast, o tyle intensyfikacja wielopłaszczyznowych przemian urbanizacyjnych paradoksalnie może zmierzać w kierunku ich dyferencjacji. Rozwojowi gospodarczemu wcale nie musi towarzyszyć intensyfikacja przemian ludnościowych bądź przestrzennych. Z innej strony, spadkowi zaludnienia miasta może towarzyszyć jego rozwój gospodarczy.

Jeśli rozpatrujemy przemiany miast w obrębie złożonych układów osadniczych, to usytuowanie w rdzeniu wyraźnie ogranicza możliwości rozwoju przestrzennego, co także wpływa na kształtowanie się zaludnienia. Tym samym nie tylko w złożonych układach osadniczych możliwe są cztery sytuacje: wzrost/spadek oraz rozwój/regres. O ile dwie pierwsze to ilościowe zmiany wielkości zjawiska, o tyle pozostałe dwie uzewnętrzniają głównie jakościowy charakter zmian. Mówiąc o rozwoju, mamy na myśli zarówno wzrost złożoności struktur, jak też pojawienie się dotąd istniejących składowych. Odwrotne tendencje odnoszą się do regresu, tj. upraszczania złożoności struktur. Szerszą dyskusję na temat tej ostatniej tendencji spotykamy w przypadku problematyki kurczących się miast.

W toczącej się dyskusji na temat utraty znaczenia bądź ograniczenia podstawowych do tej pory działalności gospodarczych wskazuje się, iż szereg miast bądź regionów pomimo modernizacji lub rewitalizacji dotychczasowej bazy ekonomicznej z trudem radzi sobie w nowej rzeczywistości gospodarczej. Istota problemu nie tkwi w wymagającej czasu adaptacji struktur organizacyjnych nowych branż gospodarki do nowych uwarunkowań funkcjonowania, lecz wynika z samego sektora egzogenicznego. Zgodnie $\mathrm{z}$ jego definicją stanowi on podstawę działalności gospodarczej miasta/regionu jako nadrzędny podsystem ekonomiczny organizujący główne relacje z innymi podsystemami. Regres bądź upadek sektora egzogenicznego oznacza nie tylko jego fizyczne ograniczenie, lecz - co równie istotne - zerwanie dotychczasowych powiązań z innymi składowymi miasta oraz jego otoczenia. Tym samym modernizacja bądź rewitalizacja to nie tylko wypełnienie dotychczasowej przestrzeni gospodarczej nowymi podmiotami, ale także zbudowanie często od nowa powiązań gospodarczo-społecznych. O ile dotychczasowe składowe sektora egzogenicznego tworzyły domknięty układ przestrzenno-hierarchiczny, o tyle nowe działalności tworzą raczej zbiór różnego typu powiązań niekoniecznie aspirujących do roli hegemona w strukturze gospodarczej miasta bądź regionu. Dowodem na to, że tak się dzieje, mogą być specjalne strefy ekonomiczne tworzone w obszarach dominujących dotąd działalności egzogenicznych. Jednym z wielu przykładów może być podstrefa tyska KSSE, gdzie w miejsce kluczowej dla miasta Fabryki Domów w 1996 r. pojawił się konglomerat branżowo różnych prywatnych firm. Jeszcze innym przykładem są kopalnie i huty stanowiące od końca XVIII w. podstawowy element sektora egzogenicznego na Górnym Śląsku. W ich miejsce najczęściej po transformacji ustrojowej lokowały się wielkopowierzchniowe obiekty handlowe, parki technologiczne, centra kulturalne, muzea techniki, tj. głównie placówki sektora endogenicznego. Paradoksalnie ograniczenie monofunkcyjności gospodarczej stwarza większe wyzwania dla miasta bądź regionu, bo wymaga większych umiejętności kreowania zrównoważonego rozwoju obszaru. 
Modelowym odzwierciedleniem bazy ekonomicznej miasta bądź regionu jest ryc. 1. Jak podkreśla Z. Chojnicki (1996), krystalizacja bazy materialnej inicjuje proces formowania się regionu. Dotyczy to także miasta. Na ryc. 1 zaznaczono to jako moment czasu t0. Wraz z biegiem lat odnotowujemy rozwój bazy ekonomicznej, a w jego obrębie dwóch zasadniczych składowych - sektora egzogenicznego (a) i endogenicznego (b), co zilustrowano poszerzaniem się kąta między liniami OX i OY. Wyznaczają one charakter kształtowania się bazy ekonomicznej w czasie. Im szerzej rozwierają się linie OX i OY, tym szybciej rozwija się baza ekonomiczna; spowolnienie bądź regres gospodarczy powoduje zwężanie się linii OX i OY. Jak łatwo się domyślić, domknięcie się przestrzeni między liniami następuje wraz z upadkiem (bankructwem) miasta, przykładowo w wyniku utraty praw miejskich, inkorporacji terytorialnej czy też fizycznego zniszczenia miasta w trakcie wojny.

Jak zauważa I. Kantor-Pietraga (2014), kluczowym zadaniem jest zachowanie względnej równowagi między sektorem egzo- i endogenicznym. Na ogół w początkowym okresie formowania się miasta/regionu sektor egzogeniczny rozwija się szybciej, później sektor endogeniczny nadrabia różnice w rozwoju. Istotne jest to, że miasta kreatywne dbają zwłaszcza o wysoką jakość przestrzeni miejskiej, zachęcając do przyjazdu ambitne, przedsiębiorcze jednostki i grupy reprezentujące nowoczesny sektor egzogeniczny. Z kolei w sytuacji wyczerpywania się dotychczasowych czynników rozwoju ograniczeniu bądź regresowi ulega najpierw sektor egzogeniczny. Tym samym granica między sektorami znajduje się w chwiejnej równowadze, przy czym w przypadku miast monofunkcyjnych gospodarczo nierównowaga jest zauważalna.

Z prezentowanego modelu bazy ekonomicznej wynika jeszcze kilka spostrzeżeń:

- W warunkach braku dostatecznych ograniczeń bądź barier rozwojowych osie OX i OY będą się dynamicznie oddalać od siebie, kreując rozwój bazy ekonomicznej miasta bądź regionu.

- W dłuższej perspektywie czasowej stopień oddalenia osi OX i OY prowadzi do formowania się różnych typów kształtowania się kąta rozwarcia między osiami - od utrzymującego się w czasie poprzez model z zaznaczającym się stałym oddaleniem między osiami, po model z osiami zbliżającymi się do siebie. Pierwsza sytuacja jest ilustracją rozwoju gospodarki, druga stabilizacji, zaś trzecia regresu. Przyjmując jeszcze dłuższą perspektywę czasową, tj. historyczny czas trwania jednostki osadniczej, ostateczną formą ilustrującą genezę, rozwój, względną stabilizację oraz regres bazy ekonomicznej jest model w kształcie liścia (ryc. 1.III). Jak łatwo zaobserwować w przyrodzie, kształty liści, tj. ich wielkość, długość, bądź szerokość, są wysoce zmienne, ale cechą wspólną jest przebiegająca wzdłuż ich osi wyraźna żyłka - w naszym przypadku odzwierciedlająca zrównoważoną proporcję między sektorem egzo- i endogenicznym.

- Kształtowanie się bazy ekonomicznej miasta bądź regionu powoduje określone oddziaływania zewnętrzne, podobnie jak i otoczenie wywiera wpływ na funkcjonowanie bazy ekonomicznej miasta/regionu. Wskazane relacje wiążą się przede wszystkim z rynkiem pracy. Rozwijające się miasto potrzebuje pracujących z obszarów otaczających bądź dalej położonych. Oprócz pracujących do prowadzenia działalności gospo- 
I

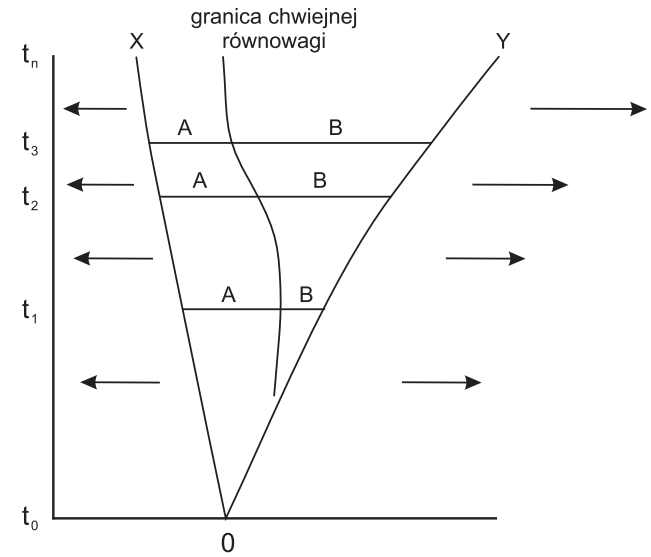

II
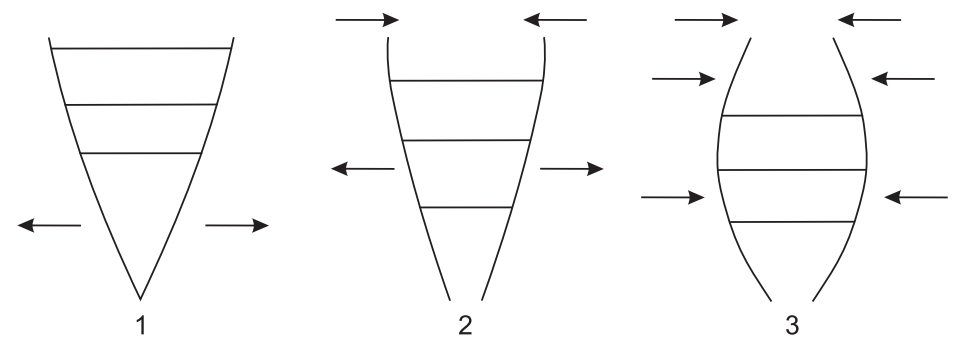

III

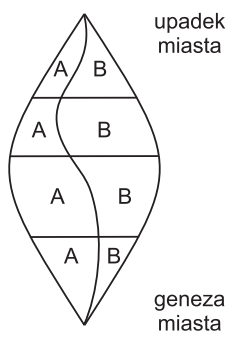

Ryc. 1. Model kształtowania się bazy ekonomicznej miasta. Objaśnienia: I - geneza i rozwój bazy ekonomicznej; II - typy modeli bazy ekonomicznej; III - model bazy ekonomicznej w całym okresie istnienia miasta; A - sektor egzogeniczny; B - sektor endogeniczny

Źródło: opracowanie własne.

darczej niezbędna jest przestrzeń, w której zlokalizowane są obiekty umożliwiające prowadzenie określonych czynności przekształcania surowców i prefabrykatów w gotowe produkty, bądź świadczenia w nich różnego typu usług. Rezultatem tych lokalizacji jest obecność w przestrzeni miasta bądź regionu obiektów sektora egzo- i endogenicznego. Pozyskiwanie pracowników niekoniecznie prowadzi do zmian przestrzennych. Bliskość terytorialna zasobów pracy kreuje jedynie powiązania funkcjonalne. Dopiero w warunkach niedostatku owych zasobów pojawia się konieczność ich trwałej alokacji w postaci migracji stałych. 
- W sytuacji bezpośredniego bądź bliskiego sąsiedztwa dynamicznie rozwijających się ośrodków miejskich możliwe są następujące sytuacje: (a) terytorialno-strukturalne przenikanie się procesów rozwojowych w warunkach braku istotnych sytuacji konfliktowych lub (b) pojawienie się ograniczeń bądź barier w rozwoju bazy ekonomicznej. Znaczna homogeniczność gospodarcza monofunkcyjnych układów osadniczych, oparta na dominacji górnictwa, hutnictwa, przemysłu maszynowego (Górny Śląsk, Zagłębie Ruhry, Zagłębie Donieckie), oraz historyczna antecedentność struktury własnościowej podmiotów gospodarczych (Rykiel 1985; 1991) powodowały wzajemne przenikanie się powiązań gospodarczych między ośrodkami miejskimi owych złożonych układów osadniczych, bez istotniejszych sytuacji konfliktowych między ośrodkami.

\section{Struktura przestrzenna}

Drugi zasadniczy element miasta bądź regionu to przestrzeń. Generalnie badania struktury przestrzennej koncentrują się na następujących zagadnieniach:

- Identyfikacji podstawowych składowych przestrzeni, najczęściej w przyjętej na potrzeby określonego badania klasyfikacji użytkowania przestrzeni. Struktura użytkowania przestrzeni miejskiej to jednak tylko jedna z wielu realnych przestrzeni. Obok niej spotykamy przestrzeń: geodezyjną, własności, zarządzania itp. (Liszewski 1997). Dopiero wszystkie razem tworzą złożony układ realnej przestrzeni miejskiej.

- Obok identyfikacji składowych przestrzeni interesują nas prawidłowości w jej kształtowaniu. Mogą one wynikać z genezy miasta, historycznych i współczesnych lokalizacji określonych funkcji, jako pochodna lokalnej, regionalnej, czy też krajowej polityki społeczno-gospodarczej.

- W konkluzji wcześniejszych zagadnień przeprowadzana jest typologia/klasyfikacja obszarów jednorodnych strukturalnie (np. tereny mieszkaniowe i ich podtypy; tereny przemysłowe i ich rodzaje).

W zależności od kształtowania się struktury przestrzennej miasta zasadniczo wyróżniamy układy regularne bądź nieregularne. Te pierwsze są pochodną długiego, historycznego trwania miasta, zaś te drugie konsekwencją burzliwych przemian urbanizacyjnych wywołanych rewolucją przemysłową. Obok tego podziału - w zależności od wielkości ośrodka - wyodrębniamy struktury przestrzenne proste i złożone. Wśród tych ostatnich spotykamy struktury układów aglomeracyjnych bądź konurbacyjnych. W analizie ładu przestrzennego, organizacji przestrzeni miejskiej układów złożonych zazwyczaj odwołujemy się do koncepcji ładu przestrzennego, modelu centrumperyferie, wieloośrodkowego modelu miasta czy też do koncepcji systemu miejskiego. W porównaniu z konceptualizacją struktury funkcjonalnej oraz demograficzno-społecznej miast próby teoretycznego ujęcia struktury przestrzennej miasta są wyraźnie skromniejsze, ograniczając się na ogół do ujęcia conzenowskiego. Wynika to głównie z braku możliwości ujednolicenia czasoprzestrzennych zmian różnych rodzajowo typów użytkowania przestrzeni. Zarówno pomiędzy klasami wielkościowymi miast, jak i w ich obrębie liczba występujących typów użytkowania przestrzeni miejskiej może być 
różna, na co nakładają się podobnie zmienne inne podziały analizowanej przestrzeni. Jednym z przykładów wewnątrzmiejskiej zmienności kształtowania się struktury przestrzennej miasta mogą być badania R. Mydla (1980; 2006) przedstawiające proces przemian struktury użytkowania ziemi, koncentracji infrastruktury technicznej oraz zaludnienia w strefach odległościowych wykreślonych wokół Rynku Głównego w Krakowie. Analiza zmian tylko tych trzech składowych od $1800 \mathrm{r}$. aż po lata powojenne pozwoliła na identyfikację szeregu odmiennych typów zmienności przyjętych cech. Generalnie uzyskane modele ilustrują proces zaniku użytków rolnych i zmniejszania się liczby mieszkańców w obszarze śródmiejskim na rzecz rozwoju infrastrukturalnego. Jednocześnie w wyodrębnionych strefach odległościowych trajektorie zmian w strukturze przestrzennej przebiegały wyraźnie odmiennie. Podobne różnice zaobserwowała B. Miszewska (1995) w analizie zmian użytkowania przestrzeni miejskiej Wrocławia.

Pojawia się zatem pytanie - czy w obrębie złożonych układów osadniczych typu konurbacji proces kształtowania się struktury przestrzennej pojedynczego miasta ma podobny charakter jak w układach aglomeracyjnych? Jedną z koncepcji umożliwiających weryfikację owej kwestii jest koncepcja systemu miejskiego (Blotenvogel 1983). W zależności od stopnia zróżnicowania bazy ekonomicznej miejscowości wchodzących w skład owego systemu możliwe są zdaniem autora trzy sytuacje:

- brak specjalizacji funkcjonalnej ośrodków, co skutkuje zanikiem powiązań między nimi;

- komplementarność funkcjonalna, co w sytuacji skrajnej dywersyfikacji prowadzi do modelu sieciowego;

- hierarchia funkcjonalna - gdy wiodący ośrodek gromadzi wyraźnie wiele funkcji, zaś pozostałe ośrodki są podporządkowane; tym samym system jako całość odzwierciedla ujęcie typu centrum-peryferie.

O ile dwa pierwsze ujęcia systemu miejskiego są raczej czysto teoretyczne, o tyle trzecie z nich - w zależności od stopnia wykształcenia hierarchii funkcjonalnej - jest zdecydowanie bliższe rzeczywistości. Potwierdzają to m.in. badania prowadzone nad strukturą funkcjonalno-przestrzenną konurbacji katowickiej (Gwosdz 2004; Gwosdz, Sobala-Gwosdz 2012; Kaszowska, Pukowska-Mitka, Runge 1992; Runge 1999; Runge, Zadrożny 1987; 1989; Spórna 2012).

Jeśli przyjmiemy, iż najbardziej adekwatnym odzwierciedleniem struktury miasta jest koncepcja systemu miejskiego, to zgodnie z ogólną teorią systemu (Bertalanffy 1968) istotna jest identyfikacja składowych struktury systemu, jego powiązań wewnętrznych i zewnętrznych oraz określenie granicy między systemem a jego otoczeniem. Jak już stwierdzono, koncepcja H. Blotenvogla (1983) traktuje poszczególne składowe systemu, tj. miasta, jako względnie równoważne wielkościowo, koncentrując się na ich zróżnicowaniach funkcjonalnych, skąd uzyskujemy generalnie trzy typy systemów miejskich (brak specjalizacji funkcjonalnej, komplementarność funkcjonalna, hierarchia funkcjonalna). Niezależnie od wariantu systemu miejskiego jego odzwierciedlenie w postaci struktury przestrzennej może być diametralnie różne, w zależności chociażby od morfogenezy, wielkości miasta, jego struktury własnościowej itp. (Liszewski 2011). 
Jeśli założyć, iż struktura przestrzenna jest pochodną kształtowania się bazy ekonomicznej miasta oraz przemian ludnościowych w określonych uwarunkowaniach czasowo-lokalizacyjnych, to zagospodarowanie przestrzeni miejskiej bądź regionalnej można traktować egzo- i endogenicznie.

W przypadku sektora egzogenicznego wpływ na przestrzeń miejską mają czynniki zewnętrzne, kreujące funkcje miastotwórcze. Z kolei w przypadku sektora endogenicznego przestrzeń miejska jest pochodną działań lokalnej społeczności (osoby, grupy społeczne, władza lokalna, przedsiębiorstwa i instytucje lokalne). Historycznie egzogeniczne formy zagospodarowania przestrzeni miejskiej sytuowały się w centrum, natomiast formy endogeniczne w obszarach zewnętrznych miasta. Te pierwsze przybierały formę reprezentacyjnych obiektów miastotwórczych (największe zakłady pracy, instytucje o znaczeniu ponadlokalnym), natomiast te drugie utożsamiamy najczęściej z zabudową mieszkaniową czy placówkami podstawowych usług dla mieszkańców. Przejście z feudalizmu do wczesnego kapitalizmu, zwłaszcza w obszarach szybko rozwijających się ośrodków i regionów przemysłowych, prowadziło do dysharmonii wcześniejszych układów przestrzennych i struktur demograficzno-społecznych (Runge A., Runge J. 2015). Wzrost liczby oraz natężenia powiązań gospodarczo-społecznych w kolejnych okresach spowodował nasilenie ruchów cyrkulacyjnych między obszarami. Jednocześnie ukształtowane wcześniej względnie stabilne struktury przestrzenno-społeczne niewielkich na ogół społeczności lokalnych ulegają dysharmonii. Na skutek rozwoju gospodarczego - często w warunkach miejscowego niedoboru zasobów pracy - intensyfikują się składowe przyrostu rzeczywistego ludności. Szybki przyrost ludności przekształca lokalne społeczności w zbiorowości o dużym odsetku imigrantów. Ich usytuowanie w przestrzeni społecznej stanowi wypadkową lokalizacji zakładów przemysłowych i przyzakładowego budownictwa mieszkaniowego, co w konsekwencji przyczynia się do postępującej segmentacji przestrzenno-strukturalnej (tereny i obiekty przemysłowe, tereny infrastruktury technicznej, dotychczasowe tereny mieszkaniowe, przyzakładowe osiedla mieszkaniowe). W miarę rozwoju gospodarczego skala i zasięg przestrzenny ruchów migracyjnych nie tylko wzrastają, ale także przyjmują nowe formy przemieszczeń. Zwraca na to uwagę w swojej koncepcji ruchliwości przestrzennej W. Zelinsky (1971).

Owe ruchy cyrkulacyjne w przestrzeni dadzą się zilustrować określonymi modelami (ryc. 2, 3). Pierwszy z modeli odzwierciedla dośrodkową cyrkulację ludności między obszarami wiejskimi i peryferyjnymi obszarami miasta a obszarem centralnym, której towarzyszą przemieszczenia odśrodkowe jako przejaw następstwa faz modelu L.H. Klaassena i J.H.S. Paelincka (1979). Efektem przestrzennym tego modelu cyrkulacji jest przede wszystkim rozwój form budownictwa mieszkaniowego. Z racji wewnątrzmiejskiej bądź wewnątrzregionalnej jego inicjacji model ten można nazwać modelem cyrkulacji endogenicznej.

$\mathrm{Na}$ omawiany model cyrkulacji endogenicznej nakłada się model cyrkulacji egzogenicznej (ryc. 4, 5), związany z kształtowaniem się struktury gospodarczej miasta, a przede wszystkim rozwojem sektora miastotwórczego. Ponieważ impulsy rozwo- 


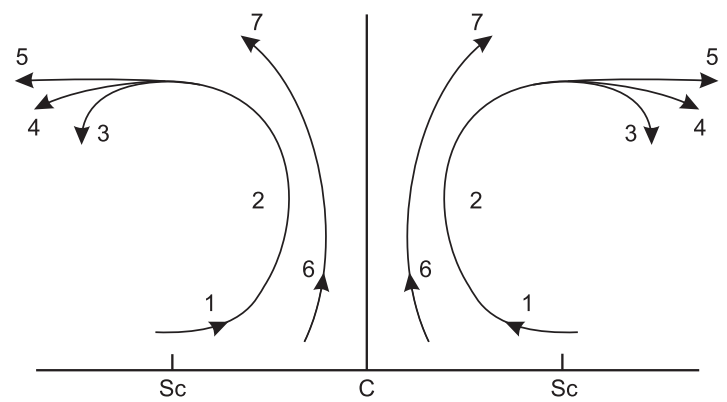

Ryc. 2. Endogeniczny model cyrkulacji procesu urbanizacji. Objaśnienia: 1 - migracja z obszarów wiejskich do miasta; 2 - migracje w dzielnicach centralnych miasta; 3 - migracje z centrum do wewnętrznych dzielnic miasta; 4 - migracje do zewnętrznych suburbiów; 5 - emigracja poza miasto; 6 - emigracja ze ścisłego centrum; 7 - emigracja ze ścisłego centrum poza miasto; C - centrum miasta; Sc - subcentra Źródło: opracowanie własne.

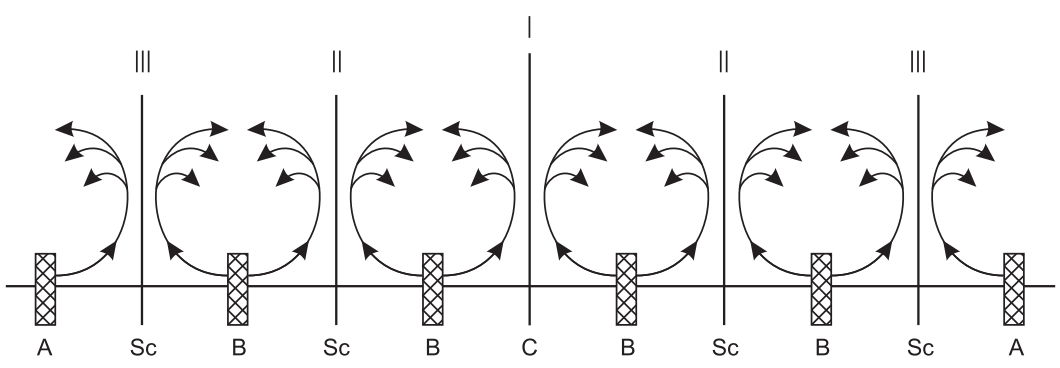

Ryc. 3. Endogeniczny model cyrkulacji procesu urbanizacji w złożonym układzie osadniczym. Objaśnienia: A, B - obszary suburbanizacji wewnętrznej; C - centrum miasta; Sc - subcentrum miasta

Źródło: opracowanie własne.

jowe docierają z zewnątrz, spoza miasta czy regionu (krajowa polityka gospodarcza, globalizacja), przebieg zmian jest odwrotny niż w modelu endogenicznym. Efektem zewnętrznego napływu inwestycji gospodarczych jest odpowiednie zagospodarowanie przestrzeni miasta. W zależności od rodzaju inwestycji, skali obiektów czy też uwarunkowań środowiskowych usytuowanie w przestrzeni zawiera się w pewnym zakresie dystansu między centrum a obszarem wewnętrznym miasta. O ile zatem historyczne preferencje lokalizacyjne budownictwa mieszkaniowego przyjmują postać fali powrotnej - z obszarów zewnętrznych miasta w stronę centrum, a następnie na peryferie, by ponownie w pewnym zakresie powrócić w stronę centrum jako przejaw reurbanizacji, o tyle gospodarcze preferencje lokalizacyjne z racji dużego strukturalnego zróżnicowania oraz inercji przestrzennej wykazują silną dyspersję terytorialną.

Endogeniczny model cyrkulacyjny w złożonych systemach osadniczych w sprzyjających warunkach lokalnych prowadzi do wykształcenia się na granicy ośrodków 


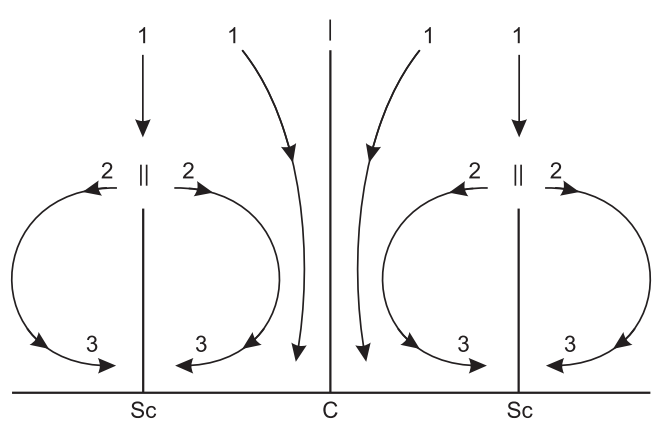

Ryc. 4. Egzogeniczny model cyrkulacji przemian gospodarczych. Objaśnienia: 1 - napływ zewnętrznych inwestycji gospodarczych do obszaru centralnego miasta; 2 - napływ zewnętrznych inwestycji gospodarczych do wewnętrznych dzielnic miasta; 3 - alokacja inwestycji gospodarczych z centrum w stronę dzielnic zewnętrznych i subcentrów; C - centrum miasta; Sc - subcentrum miasta

Źródło: opracowanie własne.

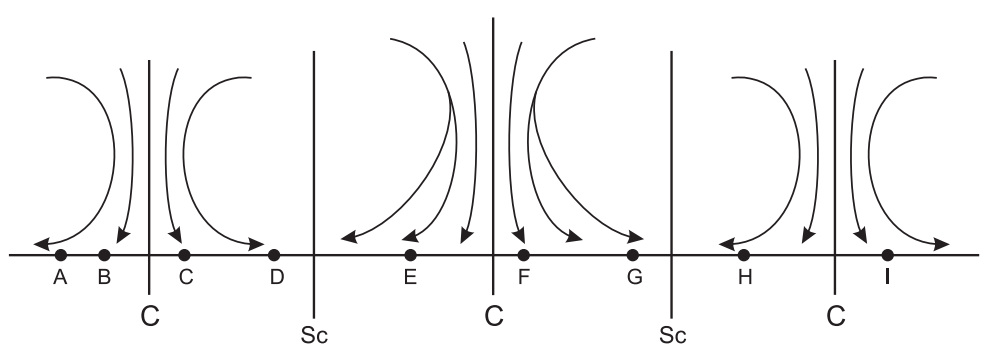

Ryc. 5. Egzogeniczny model cyrkulacji przemian gospodarczych w złożonym układzie osadniczym. Objaśnienia: C - centrum miasta; Sc - subcentrum miasta; A, B, C, D, E, F, G, H, I - lokalizacje działalności gospodarczej

Źródło: opracowanie własne.

miejskich stref suburbanizacji wewnętrznej (ryc. 3), natomiast egzogeniczny model cyrkulacji skutkuje sieciowym usytuowaniem obiektów, związanym w szeregu przypadków z wcześniejszymi preferencjami lokalizacyjnymi, priorytetami polityki lokalnej i regionalnej (ryc. 5).

Dowodem na funkcjonowanie endo- i egzogenicznej cyrkulacji w złożonym układzie osadniczym może być konurbacja katowicka. Analiza historycznego procesu kształtowania się osadnictwa tego obszaru potwierdza dośrodkowo-odśrodkowy model rozwoju zabudowy mieszkaniowej (Krzysztofik, Runge 2010). W szerszym, krajowym kontekście kształtowania się aglomeracji miejskich potwierdzają to badania R. Krzysztofika (2014). Podobnie jest w przypadku gospodarczego modelu cyrkulacji egzogenicznej. Lokalizacje głównych zakładów przemysłowych nie tylko były związane z obecnością zasobów surowcowych, ale wynikały także z sąsiedztwa innych zakładów, często powiązanych procesem produkcyjnym, wspólną infrastrukturą techniczną, co 
przekłada się na tzw. efekty mnożnikowe. Od etapu rozproszenia po czas koncentracji terytorialnej widoczne są preferencje usytuowania: w obszarach centralnych miast, w kolejno inkorporowanych obszarach sąsiadujących z danym ośrodkiem, w obszarach wydzielonych miast lub specjalnych strefach ekonomicznych poza miastami.

\section{Podsumowanie}

Przeprowadzona próba zwrócenia uwagi na niektóre kwestie konceptualizacji współczesnych przemian struktury funkcjonalno-przestrzennej miast tradycyjnego regionu ekonomicznego pozwala na kilka uogólnień. Zarówno model bazy ekonomicznej, jak również endo- i egzogeniczny model cyrkulacyjny przemian odpowiednio osadniczych i gospodarczych pozwalają na dopełnienie modelu systemu miejskiego H. Blotenvogla (1983) o bardziej realistyczne jego odniesienie do rzeczywistości. Badania historycznego procesu zagospodarowywania obszaru dzisiejszej konurbacji katowickiej jednoznacznie wskazują na dośrodkowo-odśrodkowy przebieg w tym zakresie - od XVIII-XIX-wiecznej fazy rozwoju dzisiejszego obrzeża konurbacji w stronę jego centrum po już w XX-wieczną większą aktywność mieszkalnictwa na obrzeżu tego układu osadniczego (planowa suburbanizacja lat 60. i 70. w Tychach i Dąbrowie Górniczej - Runge J., Kantor-Pietraga, Krzysztofik, Runge A. 2014; Runge, Kłosowski 2011). Z kolei w procesach gospodarczych regionalne preferencje lokalizacyjne przemieściły się z centralno-wschodniej części konurbacji w stronę zachodnią, zaś na poziomie lokalnym w wielu ośrodkach miejskich przesunęły się poza obszary dotychczasowych usytuowań, na południe od obszarów centralnych. W części wynika to z sukcesji funkcji, tj. rewitalizacji terenów poprzemysłowych i przeznaczania ich na nowe działalności. Uwzględniając fakt, iż wiele miast rdzenia konurbacji to struktury policentryczne (pochodna inkorporacji bądź połączenia sąsiadujących ze sobą miejscowości), w rezultacie uzyskujemy znaczną fragmentację funkcjonalno-przestrzenną miast.

\section{Bibliografia}

Bertalanffy L., 1968, General system theory. Foundations, development, applications, G. Braziller, New York. Blotenvogel H., 1983, Die Städte system in Nordrhein-Westfalen, [w:] Schreiber P., Weber F. (Hrsg.), Westfalen und angrenzende Regionen. Festschrift zum 44. Deutschen Geographentag in Münster, 1, Padeborn.

Chojnicki Z., 1996, Region w ujęciu geograficzno-systemowym, [w:] Czyż T. (red.), Podstawy regionalizacji geograficznej, Bogucki Wydawnictwo Naukowe, Poznań.

Friedmann J., 1967, A general theory of polarized development, Ford Foundation, Urban and Regional Development Advisory Program in Chile, Santiago.

Gwosdz K., 2004, Ewolucja rangi miejscowości w konurbacji przemysłowej. Przypadek Górnego Śląska (1830-2000), Wydawnictwo Instytutu Geografii i Gospodarki Przestrzennej, Kraków.

Gwosdz K., 2014, Pomiędzy starą a nowa ścieżką rozwojową. Mechanizmy ewolucji struktury gospodarczej i przestrzennej regionu tradycyjnego przemystu na przykładzie konurbacji katowickiej po 1989 roku, Wydawnictwo Instytutu Geografii i Gospodarki Przestrzennej Uniwersytetu Jagiellońskiego, Kraków.

Gwosdz K., Sobala-Gwosdz A., 2012, Struktura funkcjonalna i powiazania miast konurbacji katowickiej po dwu dekadach restrukturyzacji, „Przegląd Geograficzny” z. 4. 
Kantor-Pietraga I., 2014, Systematyka procesu depopulacji miast na obszarze Polski od XIX do XXI wieku, Wydawnictwo Uniwersytetu Śląskiego, Katowice.

Kaszowska B., Pukowska-Mitka M., Runge J., 1992, Wybrane aspekty rozwoju układu osadniczego woj. katowickiego w latach 1885-1992, [w:] Modrzejewski P. (red.), Wybrane zagadnienia z geografii spoteczno-ekonomicznej, Uniwersytet Śląski, Sosnowiec.

Klaassen L.H., Paelinck J.H.S., 1979, The future of large towns, "Environment and Planning. A" 11.

Krzysztofik R., 2014, Geneza aglomeracji miast na obszarze Polski, Uniwersytet Śląski, Katowice.

Krzysztofik R., Runge J., 2010, Tendencje lokalizacyjne budownictwa mieszkaniowego w miastach konurbacji katowickiej po 1945 roku a model urbanizacji, [w:] Jażdżewska I. (red.), XXIII Konwersatorium Wiedzy o Mieście. Osiedla blokowe w strukturze przestrzennej miast, Wydawnictwo Uniwersytetu Łódzkiego, Łódź.

Kunzmann K.R., 2010, Medium-sized towns. Strategic planning and creative governance in the South Baltic Arc, "Making Strategies in Spatial Planning urban and Landscape Perspectives" vol. 9.

Liszewski S., 1997, Przestrzeń miejska i jej organizacja, [w:] Domański B. (red.), Geografia - człowiek - gospodarka, Instytut Geografii i Gospodarki Przestrzennej UJ, Kraków.

Liszewski S., 2011, Geografia miasta. Założenia ogólne. Program badań, [w:] Marciniak K., Sikora K., Sokołowski D. (red.), Koncepcje i problemy badawcze w geografii, Wyższa Szkoła Gospodarki, Bydgoszcz.

Miszewska B., 1995, Strefa miejska i peryferie w powiększajacym się terytorialnie Wroctawiu, [w:] Kaczmarek J. (red.), VIII Konwersatorium Wiedzy o Mieście. Centra i peryferie dużych miast. Transformacja i przyszłość. Pojęcia i metody badawcze, Wydawnictwo Uniwersytetu Łódzkiego, Łódź.

Mydel R., 1980, Problemy rozwoju struktury przestrzennej urbanistycznych stref Krakowa, Zeszyty Naukowe Uniwersytetu Jagiellońskiego. Prace Geograficzne” z. 50.

Mydel R., 2006, Od urbanizacji do reurbanizacji. Zmodyfikowany model falowego rozwoju obszarów metropolitalnych, Akademia Pedagogiczna, Kraków.

Runge A., Runge J., 2015, Modele przestrzeni społecznej złożonych układów osadniczych (wybrane aspekty teoretyczno-empiryczne), [w:] Soja M., Zborowski A. (red.), Miasto w badaniach geografów, Instytut Geografii i Gospodarki Przestrzennej UJ, Kraków.

Runge J., 1999, Osadnictwo, [w:] Szajnowska-Wysocka A. (red.), Studium wiedzy o regionie ślaskim, Wydawnictwo Uniwersytetu Śląskiego, Katowice.

Runge J., 2015, Problemy wzrostu i rozwoju złożonych układów osadniczych, „Studia Miejskie” t. 20.

Runge J., 2016, Geograficzny wymiar modernizacji społecznej regionalnych systemów osadniczych (zarys problemu), „Konwersatorium Wiedzy o Mieście” nr 1(28).

Runge J., Kantor-Pietraga I., Krzysztofik R., Runge A., 2014, Model urbanizacji złożonych układów osadniczych w świetle procesu kurczenia się miast w Polsce, [w:] Stryjakiewicz T. (red.), Kurczenie się miast w Europie Środkowo-Wschodniej, Bogucki Wydawnictwo Naukowe, Poznań.

Runge J., Kłosowski F., 2011, Changes in population and economy in Ślaskie Voivodship in the context of suburbanization process, "Bulletin of Geography. Socio-economic series" No 16.

Runge J., Zadrożny T., 1987, Struktura społeczno-ekonomiczna województwa katowickiego, „Przegląd Geograficzny" z. 1-2.

Runge J., Zadrożny T., 1989, Delimitacja konurbacji katowickiej, [w:] Rykiel Z. (red.), Struktury i procesy demograficzno-społeczne $w$ regionie katowickim, Ossolineum, Wrocław. Prace Geograficzne IGiPZ PAN nr 151.

Rykiel Z., 1985, Zagadnienia regionalnych systemów osadniczych, PWE, Warszawa. Studia KPZK PAN t. LXXXVIII.

Rykiel Z., 1991, Rozwój regionów stykowych w teorii $i$ w badaniach empirycznych, Ossolineum, Wrocław.

Spórna T., 2012, Modele przemian urbanizacyjnych w województwie śląskim, Uniwersytet Śląski, Sosnowiec. Zelinsky W., 1971, The hypothesis of the mobility transition, "Geographical Review" 61, 2. 